\section{OLHARES REFLETIDOS}

JOAQUIM PAIVA

Rio de Janeiro, Dazibao, 1989.

- Por José Carlos G. Durand

Professor Titular do

Departamento de

Fundamentos Sociais e

Jurídicos da Administraçăo

da EAESP/FGV.

As pessoas que se declararam fotógrafos profissionais nos recenseamentos do IBGE eram 13 mil em 1960, $25 \mathrm{mil} \mathrm{em} 1970$ e $48 \mathrm{mil}$ em 1980. Assim, quase dobrando a cada década, devem hoje andar pela casa de uns cem mil. Isso sem contar os amadores, muitas vezes mais numerosos.

E claro que a grande maioria compöe-se de honestos profissionais da documentaçâo: o pessoal dos retratos $3 \times 4$, dos batizados e dos casamentos. Mas há naquelas cifras uma quantidade imponderâvel (mas certamente não desprezível) dos que querem algo mais da fotografia. Ou seja, sair do anonimato por meio de um trabalho reconhecido como obra de arte.

A grandeza dos números acima aponta para um considerável mercado para fotógrafos e até mesmo para literatura acerca de fotografia. Suficientemente amplo e diversificado a ponto de justificar, Olhares Refletidos é um interessante livro de Joaquim Paiva, em ediçāo da Dazibao, do Rio de Janeiro.

Paiva entregou-se a um trabalho engenhoso. Percorreu o país durante quase toda a década dos oitenta e entrevistou meia centena de fotógrafos. Usa no livro - segundo assegura - apenas a metade do material, decompondo vinte e cinco depoimentos em partes conforme o tema tratado. São histórias de vida de fotógrafos já com boa bagagem profissional, a média de idade de 44 anos.

$O$ autor explona, de forma adulta e despretensiosa, o material recolhido, lançando luz sobre vărias dimensöes da atividade: a iniciação, a formação, o arquivo, o trabalho de edição, o tema etc. A melhor prova do bom astral na escolha dos informantes e no manejo dos depoimentos é o tom ameno, substanciosamente informativo e muito útil para o principiante. Em um pais, como o nosso, em que muito sociólogo da cultura vive de ler e especular sem jamais sair a campo e confrontar o documento vivo, é notável o cuidado de Joaquim Paiva em colher e apresentar suas entrevistas.

Mas o livro também preenche várias outras lacunas. Lembre-se a propósito que não há antologias de fotógrafos brasileiros, faculdades ou academias que celebrem valor e imponham hierarquias nesse gênero cultural. Em suma, a "comunidade fotográfica" - no Brasil, como fora dele - é, em grande parte, invisivel, atomizada em redaçoes de jornais e revistas, agências de publicidade, ateliês, lojas de material e clubes de fotografia. $\mathrm{E}$ a carreira de fotógrafo é ainda muito pouco conhecida. Um meio assim exige forçosamente telas panorâmicas, como as de Olhares Refletidos, que por isso valem por uma exposição coletiva.

Quanto às condições de iniciação, é notável o número dos filhos de artistas plásticos $\mathrm{e} / \mathrm{ou}$ dos que freqüentavam um curso de arquitetura quando se sentiram "irresistivelmente ${ }^{y y}$ predestinados à fotografia. Tudo se passa como se um "chamamento" superior levasse aqueles jovens, já com um pé metido no campo artístico, por origem familiar, a renunciarem à arquitetura (cujo mercado de trabalho anda demasiado concorrido) e partir para uma carreira alternativa.

O sentimento de desenraizamento do cotidiano e da percepção cotidiana das coisas mostra-se algo comum quando são descritas as viagens de iniciaçäo: mergulhar no Brasil "mundo-cão", transitar pela Europa a fim de ver a obra de grandes mestres, treinar na rua aquela espécie particular de contemplaçẫo, que consiste em ficax "o tempo toto olhando com o olhar, fotografando instintivamente com a cabeça, mesmo sem máquina". Tudo isso faz parte do métier de fotógrafo. Melhor dizendo, dos hábitos mais profundos nos quais se apóia a prática fotográfica.

Revelado em múltiplas narrativas de experiências pessoais, o campo fotográfico brasileiro de hoje em dia vai aos poucos assumindo um contorno que desautoriza excessos de pessimismo. Em suma, hoje é mais fácil comprar material, encontrar um local para expor, dialogar com iniciados, descobrir um editor de fotografia que seja ele próprio fotógrafo etc. Ao final do livro de Paiva, há uma sugestiva constatação:

"O fotógrafo, para ser reconthecido como artista, precisou copiar pintura, para entrar no universo da arte. Agora que a própria pintura começa a seguir a fotografia mais do que a foto- 
grafia segue a pintura, a folografia está buscando o reconhecimento atraves da linguagem escrita. Está precisando do aval daqueles que dominam a retö rica, a palavm escrita".

Se o exemplo desse atraente livro for seguido, pode-se supor que tal legitimaçăo será alcançada, por que não? $\square$

\section{CÁLCULO: UM CURSO MODERHO E SUAS APLICAÇÓES}

LAURENCE D, HOFFMANN

Rio de Janeiro, Livros Técnicose Cientificos, 1990.

\section{Por Francisco Aranha}

Professor do Departamento de Informática e Métodos Quantitativos da EAESP/FGV e consultor de empresas.

A Editora Livros Técnicos e Científicos lançou este ano a segunda edição brasileira do curso de calculo de Laurence D. Hoffmann. Traduzida a partir da terceira edição de Calculus for Business, Economics and the Social and Life Science, da McGraw-Hill, esta nova versão recebeu em português o título de Cálcuto: um Cutso Moderno e suas Aplicaçöes.

Trata-se de um livro-texto extremamente bem adaptado ao público a que se destina. Dirigido aos estudantes dos cursos de Administração, Arquitetura, Biologia, Economia, Psicologia e Sociologia, apresenta uma abordagem voltada para aplicaçōes práticas e um tratamento intuitivo e claro dos conceitos matemáticos pertinentes. Mais do que demonstrar rigorosamente os desenvolvimentos da teoria, interessa ao autor apresentar a mecânica e a utilidade das técnicas disponíveis. De forma provocativa e instigante, Hoffmann propõe a utilização do cálculo como uma ferramenta eficaz no equacionamento dos diversos problemas que os alunos enfrentarăo em sua vida profissional.

Coerentemente com a ênfase à utilidade e à aplicabilidade da disciplina apresentada, o autor optou por uma organização temática dos tópicos estudados. Em vez de seguir o roteiro usual dos livros de calculo, em que se apresentam e demonstram passo a passo os diversos teoremas e propriedades necessários a um desenvolvimento matematicamente bem encadeado, Hoffmann faz avançar e recuar diversas vezes a teoria para ter a liberdade de esgotar as unidades de significado que soube bem identificar.

Os principais pontos fortes do texto, abordagem intuitiva e ênfase nas aplicaçôes, são também seus principais pontos fracos. Resultam numa falta de rigor e de formalizaçăo que muito provavelmente se manifestarão como uma falha na formação dos alunos que desejarem um maior aprofundamento na área de métodos quantitativos. Por exemplo: a passagem do estudo de funçöes para as técnicas de derivação, sem um desenvolvimento, ainda que mínimo, do conceito de limites, năo nos parece fornecer uma base sólida para a compreensằ da essência do cálculo. A inclusão de um breve apêndice sobre o tema antes ressalta o problema, năo o resolve.

É bem verdade que não se pode com justiça criticar um curso por năo entregar aquilo que năo promete. $O$ alerta acima deve servir mais ao interessado, como uma sugestâo no sentido de suprir um programa de estudos com títulos mais fortes no que diz respeito à teoria. $\mathrm{O}$ que não se pode perdoar é o descuido com que a presente edição foi tratada pelo editor.

Esse descuido, manifesto pelo número absurdamente alto de erros de impressão e de tradução, é duplamente censurável: trai o autor que, para garantir a correção do texto original, mobilizou uma equipe de pelo menos 22 revisores e um responsável pela precisão de exemplos e exercícios; e trai o leitor que, a cada página, deve duvidar do que lê. Fico imaginando um aluno, em especial um aluno com uma formaçẫo deficiente em matemática, que deci$\mathrm{da}$, por exemplo, ler o apêndice $\mathrm{A}$ (uma revisão de álgebra). Pergunto-me se ele se sentirá seguro o suficiente para dizer que o texto tem em média dois erros a cada três páginas, ou se, após alguns minutos de leitura, desistirá de estudar por não estar entendendo a explanação. Caso este em que o livro, em vez de ajudar, estará atrapalhando.

Em resumo, Cálculo: Um Curso Moderno e Suas Aplicações é um livro excelente dentro daquilo que se propöe a fazer, apresenta um bom índice remissivo e um inovador indice de aplicações seleciom nadas, exibe uma diagramaçăo clara, adota um formato muito confortável para a leitura. Mas fica prejudicado pelo excesso de erros de impressão e traduçâo. Talvez o mais prudente seja esperat pela próxima edição. 